\title{
Influence of Regional Financial Market Models on the Structure of Global Financial Assets
}

\author{
Olena Bulatova \\ Economics and International Economic \\ Relations Department \\ Mariupol State University \\ Mariupol, Ukraine \\ olena_bulatova@yahoo.com
}

\author{
Nataliia Reznikova \\ World Economy and International \\ Economic Relations Department \\ Institute of International Relations of \\ Taras Shevchenko National University \\ of Kyiv \\ Kyiv, Ukraine \\ r_nv@uk r.net
}

\author{
Tetiana Shabelnyk \\ Mathematical Methods and System \\ Analysis Department \\ Mariupol State University \\ Mariupol, Ukraine \\ tanya.shabelnik17@gmail.com
}

\author{
Tetyana Marena \\ Economics and International Economic \\ Relations Department \\ Mariupol State University \\ Mariupol, Ukraine \\ t.marena@mdu.in.ua
}

\begin{abstract}
The article deals with the structure of global financial assets in terms of stock market capitalization, debt securities and bank assets. The peculiarities of functioning and structure of financial markets of the American, European and Asian regions are defined. Based on the results of the regional financial markets analysis, the advisability of distinguishing corresponding regional financial market models is proved. Through the application of statistical methods, the degree of dependence of global financial assets structure on the regional financial market model is estimated. It is found out that the regional financial market model really matters for the global financial assets' composition.
\end{abstract}

Keywords-financial market, global financial assets, stock market capitalization, debt securities, bank assets, regional financial market model

\section{INTRODUCTION}

The global financial system of our times is dynamically unstable, and the new financial order is becoming increasingly more chaotic, volatile, dynamics, non-linear and highly hierarchical. The content of the notions "global financial order" and "global financial system" has been gradually changing in the process of its fragmentation under the impact of rapid creation of regional financial clusters. Regionalization has become a kind of tool for financial markets protection against the destructive effects of financial globalization and global financial crisis [1], a means of counteracting global imbalances and stabilizing financial systems at national and regional levels [2]. The processes of regionalization and related regional financing arrangements influence not only national and regional financial markets, but also modify global financial architecture and transform construction and organizational mechanism of the global financial market [3]. Regionalization of the global financial system is becoming both a response on the global demands of multinational corporations [4] and a consequence of the mission-oriented policy of national states, indented to promote the inflow of foreign direct investment and intensify their participation in the international movement of capital.
Regionalization of the global financial system constitutes a reaction on changing economic capacities of countries and regions, accompanied by respective change in the positions of international financial centers [5] and in the transformation processes in international finances that serve cross-country movements of goods and services and reallocate monetary capital between competing entities of the international market, but it is also an inevitable side effect of the monetary and currency integration. At the same time, the monetary and fiscal policy in a monetary union can change under the impact of the financial markets' integration (in particular, in order to reduce the risks associated with regional financial integration), which gives evidence of their mutual impact [6], [7], [8].

Development of regionalization processes within the global financial system entails formation of regional financial markets on the basis of megaregions and metaregions, which shape the modern spatial structure of the world economy. Cross-border capital flows connect individual local and regional financial markets to an integrated global financial space. On the other hand, there is a redistribution of global financial assets between regions of the world, and a kind of competition occurs between regional financial markets for attracting greater amount of financial assets and better access to financial resources. Given the historical and economic peculiarities of the financial systems development in different regions, there are corresponding differences in the organization and structure of regional financial markets and in the distribution of global financial assets between regions of the world.

\section{ANALYSIS OF RESEARCH AND PROBLEM STATEMENT}

Nowadays, when the concept of "global financial architecture" is revised, intra-regional integration becomes a means for countries to form a relatively viable financial market. By combining limited resources in the integrated whole they will be able of providing access to them for companies and government bodies that are in need for financial resources. On the other hand, the possibilities for 
allocating financial resources are expanding for potential investors from the region. Intra-regional integration, apart from promoting solutions to internal problems in each of the national economies, i.e. making the funds more accessible, expands economic relations between countries of this region. The proportion between the intensities of the overall economic integration and the financial integration is determined by the development of integration processes in economic and political sphere.

If the regionalization in the context of globalization processes is analyzed by three methods -1 ) regionalization as a component of globalization; 2) regionalization as a challenge or response to globalization; 3) regionalization and globalization as parallel processes [9], - then the process of global financial system regionalization will be linked to:

- The financial liberalization processes (convergent trends); scopes of the signed regional trade agreements; the extend of currency internationalization (euro in the European regions, yuan in the Asian region).

- The specifics of national economic systems' adaptation to cyclic change; the demand for creation of institutional mechanisms to reduce the dependence on international financial institutes (divergent trends).

- The degree of the countries' interdependence in trade and finance [10]; the rapidity with which innovative financial instruments are introduced, and on the participation of countries in introduction of prudential norms intended to secure the financial system from devastating effects of uncontrolled flows of speculative capital (overlapping trends).

Therefore, the global financial crisis can be regarded as a kind of trigger of financial regionalization, because it causes the increasing contagion effects [11], [12] and spillover effect, which strength correlates with the interdependence of countries with regard to finance, trade and information channels. Hence, stimuli to creation of regional financial clusters constitute a logical reaction on the increasing exposure of national financial systems to the sources of financial instability.

Developed and developing economies became more integrated as a result of the financial cointegration and globalization (due to capital market liberalization) and free trade agreements [13]. The rapid transfer of information and capital decreased long-term benefits from international diversification due to the increasing scales of cointegration. The global financial crisis and varying patterns of economic growth renewed the focus on regional solutions to common problems both in East Asia and other continents. The U.S. leadership became subject of exacerbating discontent, as global standards proved incapable to prevent the crisis and emerging economies accumulated greater amounts of foreign currency reserves. The scope of bailouts in time of global financial crisis was another factor in favor of cofinancing in many of them, which increased the position (and, therefore, influence) of regional groupings [14] and regional finances.

The trend of financial globalization was in parallel with the trend of real regionalization; it is argued that the change in international business cycles closely correlates with the growth in international asset trade. In particular, increasing globalization in financial markets is the key to accounting for less international co-movement [15].

In theoretical studies on financial markets development, the models of the national financial markets are considered and the European (continental, banking), Anglo-American and mixed models are distinguished [16], [17]. The results of empirical studies of the directions and scales of financial assets movement between countries and regions of the world are presented in the works of foreign scholars [6], [12], [14], [18] and analytical publications of the international financial organizations and research institutions - the International Monetary Fund, The World Bank, the Bank for International Settlements, the World Economic Forum, the McKinsey Global Institute, and others. Alongside it, issues of functioning and structural organization of financial markets of the global regions, which are still insufficiently considered, require special attention in terms of deepening regionalization in the financial sphere and the growth of scientific interest in the study of the regional component of global integration processes.

This study is aimed at identifying the peculiarities of structural composition of global regions financial assets, reasoning regional financial market models and defining their impact on the structure of global financial assets.

The theoretical and methodological bases of the research are the principles of modern economics, scientific works of domestic and foreign scholars in the field of financial market and global financial assets research. The information bases of the study are the statistics of the International Monetary Fund (IMF) and the Bank for International Settlements on the structure of global financial assets and indicators of financial markets. The structure of global financial assets is analyzed according to the IMF methodology, which treats financial assets as an aggregate of stock market capitalization, debt securities and bank assets. The study is carried out using historical and logical methods, methods of structural and functional, comparative and system analysis, statistical methods, including dispersion analysis.

\section{RESEARCH RESULTS}

The dynamic development of the world financial market under the influence of globalization processes has led to the fact that the aggregate size of global financial assets (stock market capitalization, debt securities and bank assets) began to exceed world production significantly: in 2018, the rate of the global economy financialisation (the ratio of global financial assets to world GDP) exceeded $420 \%$ (for comparison: in 2003 the level of financial depth was over $300 \%$ ). All this growing mass of global financial assets is unevenly distributed among countries and regions of the world economy. The numerous transformations taking place in the global financial system in terms of globalization lead to even more significant shifts in the directions and scales of capital redistribution, both in the social and economic and in the spatial (regional) dimensions.

The spatial structure of global financial assets by countries is highly concentrated: in 2018, the United States and the EU allocated $35 \%$ and $22 \%$ of assets respectively, together accounting for more than half of all financial resources of the world. In the regional context, over time, the shifts in the allocation of global financial assets across the 
regions of the world are becoming increasingly evident. The share of financial assets of the American region is comparatively stable (it decreased to $30 \%$ in the period of global financial crisis and now it has so far recovered, amounting to nearly $40 \%$ ), which is presented in Table I.

TABLE I. REGIONAL STRUCTURE OF GLOBAL FINANCIAL ASSETS BY TYPES OF ASSETS IN 2003-2018, PER CENT ${ }^{\mathrm{a}}$

\begin{tabular}{|c|c|c|c|c|c|c|c|c|c|}
\hline Region & ๕̊ & ஓ্ণ & 곡 & 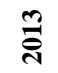 & ষ্ণ & $\frac{n}{8}$ & ํㅡㄹ & 동 & $\stackrel{\infty}{\stackrel{\overbrace{}}{1}}$ \\
\hline \multicolumn{10}{|c|}{ Global financial assets, total } \\
\hline American & 37.3 & 30.2 & 31.0 & 31.6 & 39.1 & 38.9 & 39.9 & 37.1 & 39.9 \\
\hline European & 35.1 & 40.9 & 33.9 & 33.9 & 29.1 & 27.3 & 25.0 & 23.5 & 24.8 \\
\hline Asian & 23.1 & 21.9 & 27.9 & 27.5 & 27.6 & 29.7 & 31.0 & 31.2 & 32.0 \\
\hline $\begin{array}{l}\text { Other } \\
\text { countries }\end{array}$ & 4.5 & 7.0 & 7.2 & 7.0 & 4.3 & 4.1 & 4.1 & 8.2 & 3.3 \\
\hline \multicolumn{10}{|c|}{ Stock market capitalization } \\
\hline American & 50.5 & 42.5 & 40.4 & 42.5 & 44.5 & 41.7 & 44.4 & 44.3 & 49.8 \\
\hline European & 25.3 & 23.5 & 21.7 & 22.3 & 20.3 & 20.1 & 15.4 & 14.5 & 16.1 \\
\hline Asian & 23.4 & 25.5 & 29.2 & 27 & 29.1 & 32.7 & 34.5 & 36.1 & 31.7 \\
\hline $\begin{array}{l}\text { Other } \\
\text { countries }\end{array}$ & 0.8 & 8.5 & 8.7 & 8.2 & 6.1 & 5.5 & 5.7 & 5.1 & 2.4 \\
\hline \multicolumn{10}{|c|}{ Debt securities } \\
\hline American & 43.9 & 40.7 & 41.3 & 41.4 & 43.7 & 44.5 & 44.6 & 37.7 & 43.8 \\
\hline European & 33.0 & 35.8 & 30.9 & 32.2 & 32.8 & 29.9 & 27.9 & 26.2 & 27.3 \\
\hline Asian & 19.5 & 19.5 & 22.6 & 21.2 & 20.7 & 23.0 & 24.9 & 23.4 & 26.5 \\
\hline $\begin{array}{l}\text { Other } \\
\text { countries }\end{array}$ & 3.6 & 4.0 & 5.2 & 5.2 & 2.8 & 2.6 & 2.6 & 12.7 & 2.4 \\
\hline \multicolumn{10}{|c|}{ Bank assets } \\
\hline American & 18.6 & 18.0 & 18.6 & 18.8 & 34.1 & 34.5 & 35.2 & 33.3 & 33.9 \\
\hline European & 45.6 & 50.9 & 41.6 & 40.8 & 30.8 & 28.9 & 27.5 & 29.1 & 26.8 \\
\hline Asian & 26.0 & 22.7 & 31.5 & 32.5 & 30.8 & 32.3 & 33.0 & 34.0 & 35.2 \\
\hline $\begin{array}{l}\text { Other } \\
\text { countries }\end{array}$ & 9.8 & 8.4 & 8.3 & 7.9 & 4.3 & 4.3 & 4.3 & 3.6 & 4.1 \\
\hline
\end{tabular}

The European region accounts for decreasing part of financial resources: its share in regional structure of global financial assets has declined from $35.1 \%$ in 2003 to $24.8 \%$ in 2018. At the same time, there is an increase in the saturation with financial resources of the Asian region, which share for the analyzed period increased from $23.1 \%$ to $32.0 \%$. One of the main factors contributing to this is the growing importance of the Chinese financial market (which accounts for $15.0 \%$ of global financial assets) both at the regional and global levels: nowadays China is one of the main exporters of capital; it has significant international reserves, serves as the location of several leading international financial centers and the country of origin of the biggest transnational banks.

Thus, today there is an obvious redistribution of global financial assets between the European and Asian regions. Similar changes are observed in different segments of the global financial market, namely in stock and debt securities markets and in the bank assets structure (see Table 1).

The high rate of global financial assets concentration in the three mentioned regions allows to distinguish three biggest regional financial markets, namely American, European and Asian markets. Each of these regional markets has its own organization and structure, due to the social and economic, historical, institutional and other features of the respective regions' development. The common feature of the financial markets of the American, European and Asian regions is the predominance of bank assets, which share in the structure of financial assets of all regions is increasing (Table 2).
The main owners of these assets are transnational banks and their associations, which occupy leading positions in the global and regional financial markets. In general, recently, the role of banks in financing the countries' economic development has increased significantly, mainly due to a certain curtailment of external financing owing to the global financial crisis. In particular, the following factors contributed to the increase in the share of bank assets in the structure of regions' financial assets: the global liquidity crisis, which was accompanied by a decrease in the activity of operators of the global and regional capital markets and international investment cutback; an outflow of foreign investment from emerging markets.

TABLE II. STRUCTURE OF FINANCIAL ASSETS OF THE AMERICAN, EUROPEAN AND ASIAN REGIONS IN 2003-2018, PER CENT ${ }^{\mathrm{a}}$

\begin{tabular}{|c|c|c|c|c|c|c|c|c|c|}
\hline $\begin{array}{l}\text { Type of } \\
\text { financial } \\
\text { assets }\end{array}$ & ฮิণ & 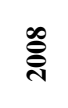 & 궁 & $\stackrel{m}{\vec{N}}$ & $\underset{\nabla}{\stackrel{\sim}{*}}$ & 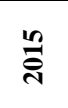 & 웡 & 혹 & $\stackrel{\infty}{\stackrel{\sim}{二}}$ \\
\hline \multicolumn{10}{|c|}{ American region } \\
\hline $\begin{array}{l}\text { Stock market } \\
\text { capitalization }\end{array}$ & 34.0 & 21.3 & 25.2 & 28.6 & 24.8 & 23.2 & 24.3 & 26.4 & 24.4 \\
\hline $\begin{array}{l}\text { Debt } \\
\text { securities }\end{array}$ & 48.6 & 50.7 & 48.2 & 46.0 & 31.8 & 32.8 & 32.0 & 30.7 & 32.1 \\
\hline Bank assets & 17.4 & 28.0 & 26.6 & 25.4 & 43.4 & 44.0 & 43.7 & 42.7 & 43.5 \\
\hline \multicolumn{10}{|c|}{ European region } \\
\hline $\begin{array}{l}\text { Stock market } \\
\text { capitalization }\end{array}$ & 16.5 & 8.8 & 12.4 & 15.0 & 15.3 & 16.0 & 13.4 & 11.5 & 12.6 \\
\hline $\begin{array}{l}\text { Debt } \\
\text { securities }\end{array}$ & 35.8 & 33.3 & 33.0 & 33.7 & 32.1 & 31.4 & 32.1 & 33.2 & 32.1 \\
\hline Bank assets & 47.7 & 57.9 & 54.6 & 51.3 & 52.6 & 52.6 & 54.5 & 55.3 & 55.3 \\
\hline \multicolumn{10}{|c|}{ Asian region } \\
\hline $\begin{array}{l}\text { Stock market } \\
\text { capitalization }\end{array}$ & 25.7 & 17.6 & 20.2 & 22.0 & 23.0 & 23.8 & 24.3 & 25.7 & 19.3 \\
\hline $\begin{array}{l}\text { Debt } \\
\text { securities }\end{array}$ & 32.0 & 33.4 & 29.4 & 26.8 & 21.4 & 22.2 & 23.0 & 22.7 & 24.3 \\
\hline Bank assets & 42.3 & 49.0 & 50.4 & 51.2 & 55.6 & 54.0 & 52.7 & 51.1 & 56.4 \\
\hline
\end{tabular}

The growth of the bank assets share in the total amount of regions' financial resources is accompanied by changes in the directions of banking activities. Some banks have reduced the scope of their cross-border activities and have reoriented to domestic operations under the influence of the following factors: banks have reassessed the risks of host countries; cross-border business has appeared to be less profitable than domestic one for many banks; central banks of a number of countries began to pursue a policy of promoting domestic lending; cross-border financial transactions lead to an increase in the scale and complexity of banking activities, which can entail the problems of compliance with capital adequacy and liquidity ratios [22].

After the introduction of the Euro, banks in the euro area started to expand actively into foreign markets. The size of their foreign claims has grown from 4.3 trillion dollars in 2000 to 15.9 trillion dollars in 2007 , making them the most globalized banks in the world. Nowadays, the banks in the euro area are characterized by the greatest collapse of crossborder activity - foreign loans and other claims of these banks from 2007 to 2016 decreased by 7.3 trillion dollars or by $45 \%$ [22]. Banks cut their foreign operations by reducing cross-border assets and giving up short-term lending on interbank markets. On the other hand, the curtailment of foreign activity of the euro area banks is accompanied by internal operations recovery: the volume of domestic lending 
in a number of the euro area countries is currently greater than before the global economic crisis.

Some European banks outside the euro area (in Switzerland and UK) as well as some American banks cut down their foreign business too. Swiss and British banks reduced their foreign claims by 2.1 trillion dollars or $32 \%$. Similarly, some of the biggest US banks have limited their presence in foreign markets by liquidating overseas subdivisions and reducing the number of correspondent banking relations. In contrast, banks from Canada, Japan, as well as some developing countries, including China, pursue a policy of expansion into foreign markets. Comparing to 2007, Canadian and Japanese banks have doubled their foreign claims. Today $50 \%$ of the Canadian banks' assets are represented by foreign claims. Since 2007, four biggest Chinese banks have increased foreign assets four times; the volume of their foreign assets is over 1 trillion dollars or $9 \%$ of total assets of these 4 banks.

The study of the construction of financial markets in the American, European and Asian regions from the point of view of their financial assets structure allowed to determine specific features of the structural composition of the regional financial markets and to identify the relevant regional financial markets models. In the pre-crisis period and in the first years after the global crisis, the American region was characterized by the prevalence of debt financing and the share of debt securities in financial assets structure was in the range of 46-51\%. Starting from 2014 against the background of bank assets growth (their share increased from $17.4 \%$ in 2003 to $43.5 \%$ in 2018), the decrease in shares of stock market capitalization and debt securities is observed. As a result, today the financial assets structure of the American region is relatively balanced (stock market capitalization, debt securities and bank assets account for $24.4 \%, 32.1 \%$ and $43.5 \%$ of financial assets respectively). The region rapidly builds up financial assets, which total volume for the analyzed period has increased three times (growth rate is $302.5 \%$ ). Accordingly, it is proposed to distinguish the American regional model of the financial market, which is characterized as balanced, dynamic, of a mixed type demonstrating a moderate predominance of banking.

The European region proved to be more conservative in the context of time changes in the construction of the regional financial market: during the analyzed period, bank assets prevail in the financial assets structure, accounting for $55.3 \%$ today. Debt securities run the second, accounting for one third of financial assets. At the same time, the European region lags far behind American region in terms of growth rates of financial assets, which from 2003 up to now haven't even doubled (growth rate is $183.0 \%$ ). Consequently, the European regional model of the financial market can be characterized as highly concentrated banking, moderately debt, conservative and slowly dynamic.

In the Asian region, the redistribution of financial resources takes place between the debt securities market (its share decreased from $32.0 \%$ to $24.3 \%$ ) and bank assets (their share increased from $42.3 \%$ to $56.4 \%$ ), while the share of the stock market capitalization in the financial market structure is relatively stable (19-26\%). The financial assets growth rate in the Asian region is the highest one among the regions under consideration amounting to $368.7 \%$. Thus, the Asian regional model of the financial market is concentrated banking, moderately investment and debt, highly dynamic.

Having the specific construction of financial markets by types of financial assets, the leading regions of the world actually determine the structure of global financial assets and stipulate the changes that take place in it. On the basis of the dispersion analysis of statistical data on the regional structure of global financial assets by types of assets presented in Table 1, the dependence of the formation of the different financial assets structure on regional financial markets models under a significance level of $\alpha=0.05$ was determined, considering that all generic units are normally distributed and have the same dispersion.

Table 3 presents the results of a one-factor dispersion analysis to identify the impact of regional financial market models on the intensity of structural shifts in the world financial market in terms of different financial assets such as stock market capitalization, debt securities and bank assets.

TABLE III. RESULTS OF THE DISPERSION ANALYSIS

\begin{tabular}{|c|c|c|c|c|c|c|}
\hline $\begin{array}{c}\text { Sources of } \\
\text { variation }\end{array}$ & SS & df & MS & $\mathbf{F}$ & $\begin{array}{c}\mathrm{P}- \\
\text { value }\end{array}$ & $\begin{array}{c}\text { F- } \\
\text { critical }\end{array}$ \\
\hline \multicolumn{7}{|c|}{ Stock market capitalization } \\
\hline $\begin{array}{l}\text { Between } \\
\text { the groups }\end{array}$ & 7240.29 & 3 & 2413.43 & 187.302 & \begin{tabular}{|l}
2.27031 \\
E-18
\end{tabular} & 2.9011 \\
\hline $\begin{array}{l}\text { Inside of } \\
\text { the groups }\end{array}$ & 412.326 & 32 & 12.885 & & & \\
\hline \multicolumn{7}{|c|}{ Debt securities } \\
\hline $\begin{array}{l}\text { Between } \\
\text { the groups }\end{array}$ & 6833.94 & 3 & 2277.98 & 291.604 & $\begin{array}{l}2.62578 \\
\text { E-20 }\end{array}$ & 2.9011 \\
\hline $\begin{array}{l}\text { Inside of } \\
\text { the groups }\end{array}$ & 249.980 & 32 & 7.811 & & & \\
\hline \multicolumn{7}{|c|}{ Bank assets } \\
\hline $\begin{array}{l}\text { Between } \\
\text { the groups }\end{array}$ & 4613.11 & 3 & 1537.70 & 35.763 & \begin{tabular}{|l}
2.46126 \\
E-09
\end{tabular} & 2.9011 \\
\hline $\begin{array}{l}\text { Inside of } \\
\text { the groups }\end{array}$ & 1375.87 & 32 & 42.995 & & & \\
\hline
\end{tabular}

Based on the analysis of such calculated data as the sum of the deviations squares (SS), the number of degrees of freedom (df), dispersion (MS), the actual value of Fisher's ratio $(\mathrm{F}), \mathrm{p}$-value, Fisher's critical value (F-critical), the following conclusions are made. For the stock market capitalization indicator, the actual value of Fisher's ratio is greater than the critical value, the value of the p-value, which expresses the probability that the criterion statistic falls into the critical area, does not exceed the level of significance set in the terms. This means that, with a probability of $95 \%$ for the period of 2003-2018, regional financial market models have a significant impact on the formation of the stock market structure. Similarly, the results of the dispersion analysis for the indicator of debt securities and the indicator of bank assets show that with a probability of $95 \%$ for the period 2003-2018, regional financial market models have a noticeable influence on the formation of the debt securities market and the bank assets structure. Thus, it is proved that the dynamic changes in the structure of global financial assets are under the influence of American, European and Asian regional models of the financial market.

\section{CONCLUSIONS}

Regionalization processes today lead to significant changes in global financial system causing formation of regional financial markets on the basis of mega- and metaregions. Regionalization of the global financial system 
constitutes a reaction on changing economic capacities of countries and regions, accompanied by respective changes in the positions of international financial centers and in the transformation processes in international finances, but it is also an inevitable side effect of the monetary integration. As a result of the assessment of the regional structure of global financial assets and their types (stock market capitalization, debt securities and bank assets), it is determined that nowadays the redistribution of global financial assets between European and Asian regions is observed in the favor of the latter, while the share of the American region is relatively stable. Given the high level of global financial assets concentration in three mentioned regions, three major regional financial markets are defined, namely American, European and Asian, each with a specific organization and structure, due to the economic, historical and institutional features of the global regions' development. It is found out that the common feature of the American, European and Asian financial markets is the predominance of bank assets in their financial assets structure, which testifies to the growing role of banks in financing the economic development of countries and regions. Changes in directions of banking activities related to the reduction of cross-border activities by many international banks and their reorientation to domestic operations are revealed. Theoretical approaches to the study of financial markets have been developed by reasoning regional financial market models and identifying their characteristic features. In particular, based on the results of study of the financial markets construction in the American, European and Asian regions, the dynamics and structures of their financial assets, it is proposed to distinguish the following regional financial markets models:

1) American model - balanced, of a mixed type demonstrating a moderate predominance of banking, dynamic.

2) European model - highly concentrated banking, moderately debt, conservative, slowly dynamic.

3) Asian model - concentrated banking, moderately investment and debt, highly dynamic.

On the basis of the dispersion analysis method application, the degree of dependence of the intensity of structural shifts of the world financial market in terms of different financial assets on the regional financial market models is estimated. It is found out that dynamic changes in the structure of global financial assets take place due to the impact of structural shifts in American, European and Asian financial markets. Given the specificity of the leading regional financial markets construction, it is proved that the types of regional financial market model are significant for the structural composition of global financial assets.

\section{REFERENCES}

[1] P.R. Lane, and G.M. Milesi-Ferretti, "The external wealth of nations revisited: international financial integration in the aftermath of the global financial crisis”, IMF Economic Review, vol. 66(1), pp. 189222, March 2018

[2] L. Mühlich, Advancing regional monetary cooperation: The case of fragile financial markets. London: Palgrave Macmillan, 2014.

[3] M. Kawai, and D. Lombardi, Financial regionalism and the international monetary system. Brookings Institution Press, December, 2015.

[4] S. X. B. Zhao, J. M. Cai, and L. Zhang, "Asymmetric information as a key determinant for locational choice of MNC headquarters and the development of financial centers: a case for China", China Economic Review, vol. 16(3), pp. 308-331, 2005.

[5] S. X. B. Zhao, L. Zhang, and D. T. Wang, "Determining factors of the development of a national financial center: the case of China", Geoforum, vol. 35(5), pp. 577-592, 2004.

[6] H. Egger, and J. Falkinger, "International trade and financial integration under technological specialization and uncertainty", in Proc. CESifo Area Conference on Global Economy, Munich, 2015, pp. 1-40.

[7] C. Pierdzioch, Financial market integration and business cycle volatility in a monetary union: Kiel Working Paper, no. 1115, July 2002. [Online]. Available: https://www.ifwkiel.de/fileadmin/Dateiverwaltung/IfW-Publications/system/financialmarket-integration-and-business-cycle-volatility-in-a-monetaryunion/kap1115.pdf. Accessed on: Jul. 16, 2019.

[8] U. Volz, "Regional financial integration in East Asia against the backdrop of recent European experiences", International Economic Journal, vol. 30(2), pp. 272-293, 2016.

[9] A. M. Kacowicz, "Regionalization, globalization, and nationalism: convergent, divergent, or overlapping?", Alternatives: Global, Local, Political, vol. 24, no. 4, pp. 527-556, 1999.

[10] K. Forbes, and R. Rigobon, "No contagion, only interdependence: Measuring stock market co-movements", J. Finance, vol. 57, pp. 2223-2261, 2002.

[11] R. Dornbusch, Y.C. Park, and S. Claessens, "Contagion: understanding how it spreads", The World Bank research observer, vol. 15, pp. 177-197, 2000.

[12] L. Morales, and B. Andreosso-O'Callaghan, "The global financial crisis: World market or regional contagion effects?", International Review of Economics and Finance, vol. 29, pp. 108-131, 2014

[13] S. Gulzar, G. M. Kayani, H. Xiaofeng, U. Ayub, and A. Rafique, "Financial cointegration and spillover effect of global financial crisis: a study of emerging Asian financial markets", Economic Research, vol.32:1, pp. 187-218, 2019. doi: 10.1080/1331677X.2018.1550001.

[14] W. Grimes, Financial regionalism after the global financial crisis: regionalist impulses and national strategies. In the consequences of the global financial crisis: the rhetoric of reform and regulation. UK: Oxford University Press, 2012. [Online]. Available: https://www.oxfordscholarship.com/view/10.1093/acprof:oso/978019 9641987.001.0001/acprof-9780199641987-chapter-6. Accessed on: Jul. 14, 2019.

[15] J. Heathcote, and F. Perri, "Financial globalization and real regionalization", Journal of Economic Theory, vol. 119, pp. 207-243, 2004.

[16] F. Zogning, "Comparing financial systems around the world: capital markets, legal systems, and governance regimes", Economics, Management, and Financial Markets, vol. 12, no. 4, pp. 43-58, 2017.

[17] Z. S. Moradia, M. Mirzaeenejadb, G. and Geraeenejadb, "Effect of bank-based or market-based financial systems on income distribution in selected countries", Procedia Economics and Finance, vol. 36, pp. 510-521, 2016. doi:10.1016/S2212-5671(16)30067-3

[18] A. Enders, Z. Enders, and M. Hoffmann, "International financial market integration, asset compositions, and the falling exchange rate pass-through", Journal of International Economics, vol. 110, pp. 151175, Jan. 2018. doi:10.1016/j.jinteco.2017.11.002.

[19] Bank for International Settlements Statistics: Credit to the nonfinancial sector. [Online]. Available: https://www.bis.org/statistics /totcredit.htm. Accessed on: Jul. 14, 2019.

[20] Bank for International Settlements Statistics: Debt securities statistics. [Online]. Available: http://www.bis.org/statistics/secstats.htm. Accessed on: Jul. 14, 2019.

[21] Global Financial Stability Report. Washington: IMF, 2003-2019. [Online]. Available: https://www.imf.org/en/Publications/GFSR. Accessed on: Jul. 14, 2019.

[22] S. Lund, E. Windhagen, J. Manyika, P. Härle, J. Woetzel, and D. Goldshtein, The new dynamics of financial globalization. McKinsey Global Institute, August 2017. [Online]. Available: https://www.mckinsey.com/ /media/McKinsey/Industries/Financial\% 20Services/Our\%20Insights/The $\% 20$ new $\% 20$ dynamics $\% 20$ of $\% 20$ fin ancial\%20globalization/Financial\%20globalization_Full\%20Report_ August_29 2017\%20(1).ashxю Accessed on: Jul. 14, 2019. 